\title{
Political Parties and Their Role in the Systems of Government
}

\author{
PhD. Cand. Vait QERIMI \\ Lecturer in College of "Gjilan" and Assistant at UP "Kadri Zeka" in Gjilan \\ vaidqerimi@hotmail.com
}

\begin{abstract}
In modern democracies, political parties have a very important political role. The existence of political parties is vital for the functioning of democracy. Political parties remain the cornerstone of the systems of government, and without their presence and operation, it is impossible to talk about the system and democratic institutions. Governance in a democracy means to and through political parties. Political parties and competition between them create the political system. Political parties constitute the central object of political sciences and they are almost always the main protagonists in the political systems. They undoubtedly represent the political power and the motor of parliamentarianism. Through the parliamentary action, the political parties build and operate the entire state structure of a state, regarding the functioning of parliament, the government, the head of state, to the local government bodies and other political institutions. Political parties are the socially dynamic forces representing one of the most significant achievements of democracy. This is well-argued with their very central role and crucial importance of the parties.
\end{abstract}

Keywords: political party, political system, pluralism, inner democracy.

\section{Introduction}

Politics is considered an organized process of living together in a society. In terms of democracy, every citizen can participate in this process through a free access to information, which deal with political issues, through the construction of expectations, proposals or requests, without fear of repression, through voting in elections, through an active engagement of civil society or political party or through democratic election candidacy. In this way, democracy represents "government of the people, by the people and for the people", to recall the famous words of Abraham Lincoln, the former President of the United States of America in the period 1961-65.

In order to fully meet the requirements for a government that is "of the people, by the people and for the people", politics in democracy must meet certain conditions, such as:

- Politics need ideas and values that set goals and standards of political organization. Freedom, justice and solidarity are the core principles which could lead to a political organization of society.

- Politics needs such social organizations, which will recognize the interests, will combine the same and will communicate with governmental institutions and the parties as well. Political parties themselves, business, labour associations and civil society with non-governmental organizations represent such kind of organizations, which can identify and bring together social interests.

- Politics need for institutions which collect proposals for the organization of society, and which are then presented, discussed and then making decisions and implementing them based on that platform. Parliaments and governments, who usually rely on political parties, represent the most important institutional policies in a democratic state.

Politics need active citizens who participate in political discussions with their ideas, demands and expectations and who actively contribute to the functioning of political institutions. ${ }^{1}$

\footnotetext{
1 Wilhelm Hofmeister and Karsten Grabow 'Political parties', Scopje, 2013, p. 11.
} 
All these measures aim to contribute to the development and consolidation of democracy. Modern democracy needs wellstructured political parties that represent the will and interests of the citizens' and they must be more authentically oriented, which could provide adequate space for political engagement in order to influence policy and political decisions.

\section{WHAT THE PARTIES ARE AND HOW WERE THEY CREATED}

Many researchers have been trying to find the origin of the creation of political parties in the legislative chain of the governance. According to them, the political parties emerged with the fall of autocratic rule, as a means to defying of this rule and to achieve representative government and were institutionalized with the expansion of the electorate, as a link to connect it to the legislature. Although the term political party has been used long times ago, we can say that they took today's meaning when modern politics configured itself regarding to participation, especially electoral system, and when it becomes more and more competitive, as well as when the governmental functions and representation are given through electoral consultation. ${ }^{1}$ Since this momentum comes, the candidates for these positions feel the need for an organization of coordinating their electoral and political activities in terms of unifying their platforms with the other candidates who share common positions. This phenomenon started from within the Parliament initially, when the Parliamentary groups began promoting their political organizations within their electoral corpuses, as well as from outside the parliament, when the parliamentary groups of organized opponents outside parliament in order to protect their interests use the existing social networks such as unions. ${ }^{2}$ In order to take control over the Parliament, new parties were formed within and outside parliament. In the first case we are dealing with parties called "parliamentary ones", in the second, with "extra-parliamentary parties", as well the organised parties against the "parliamentary bourgeois policy ", called "antiparliamentary parties".

The history of political forces in Albania commenced with the moment of creating of the first parliamentary institution in 1920. ${ }^{3}$ Before the creation of the National Council in Congress of Lushnja, when the first Albanian parliament composed of 37 members, there were no political forces in Albania. On the $10^{\text {th }}$ of Octobre 1920, a group of MPs declared the political program of National People's Party. Political leaders of this group were Fan Noli, Ahmet Zogu, Eshtref Frashëri, Luigj Gurakuqi, etc. About a month later, in November 1920, some other MP announced the creation of another political force called the Progressive Party of Albanians. The party had as leading figures from the north known as Hodja Kadri, Hasan Prishtina, Bajram Curri but also one of the richest Beys of Albania, Shefqet Vërlaci. Together with them, there were also included a number of Beys, the chairman of the tribes of the North and nationalists. Despite the political program announced by them, they were not such organised political parties, but they might be considered more as motivated groups to take power. On the other hand, democracy, as an alternative of political pluralism, is a new experience for Kosovo as well. Although multi-party system is installed at the same time when political pluralism was spread throughout South-East, the conditions of repression under which situation Kosovo was found, and this came since the abolition of its autonomy from Serbia in 1989, it did not allow room or space for any genuine pluralistic and democratic political system to be developed. Although during the 1990s, in Kosovo there were acting more than a political party, such as: the Democratic League of Kosovo, Social Democratic Party of Kosovo, the Kosovo Parliamentary Party, Christian Democratic Party and the Liberal Party are some of the parties that existed before the war - however these parties do not operate in an environment that was actually allowed such a normal political life and democracy. ${ }^{4}$

The tendency of finding a single definition for political parties seems almost impossible, even though the core of the different formulations is almost the same. The substance of its meaning becomes quite clear if the definition includes the core role of what constitutes a party. According to a classic definition: "the parties are in their inner core organizations created freely on the basis of free and fair recruitment where they had always intended to demand the vote in the elections' process in order to ensure their political positions". ${ }^{5}$ According to another more comprehensive definition ${ }^{6}$, it could be considered the definition according to which "the political parties represents the freely united citizens with their unique views, which, for the

\footnotetext{
1 Ylli Bufi, The temple of Democracy,Tirana 2010, p. 123.

2 lbid. p.124

3 See: Afrim Krasniqi, The Political parties and the political systems, Tirana, 2008.

${ }^{4}$ KIPRED, Empowering of the State of Kosovo through the Democratisation of the political parties, Prishtina, 2012, p.8

5 Max Weber,(1864-1920), The well known German Sociologist and philosopher referred in: "G.Pasquino, Nuovo corso di scienza,II Mulino, 2009, p.146.

${ }^{6}$ Afrim Krasniqi, The Political parties and the political systems, Tirana, 2008, p.37. 
resolution of their political problems and programmatic proposals, agree on submitting the candidates for seats in parliament and positions into government, that after the successful elections will be pressured to keep their program. "

\section{Some basic features of political partie}

Given the definition of political parties we can point out some of the basic features of political parties: - Political parties are institutions and voluntary political organizations that will gather people with similar orientations and political definitions.

- The fundamental purpose of political parties is participation in political life in order to obtain, preserve or participate in the state.

- Political parties exert their political influence within the institutions of the parliamentary system, which are subject of pluralistic political competition with other political parties.

- Political parties as organizations and political institutions have internal organizational structures. They have their own organised territorial network and their governing bodies.

- Political parties, articulate their orientating platforms through their political programs, which express the goals and directions of their political activity.

- Political parties have their membership which depending on its toll expresses their real strength. Political party membership is made on a voluntary basis by setting the free position of citizens.

- Political parties struggle for receiving, storing or participating in free and direct presidential and parliamentary elections sponsored and hold under the state supervision. Free, fair and direct parliamentary democracy countries represent the only indicator of the political credibility of political parties.

From the mentioned characteristics of the political parties, they represent the mainstream of institutional form of politically organised citizens within a political organization with the aim of realizing a common political interest. They represent political dominant factor determining the political process in the framework of a state. ${ }^{1}$ They form and function without any major restrictions. Nowadays, only in a small number of countries is prohibited the formation of political parties. This happens in some socialist countries that despite the movements of contemporary political trends, they still maintain their systems and totalitarian monism (i. e. Cuba, Vietnam, South Korea, China. etc).

Regarding the formation of political parties, in comparative political theory there are defined three general conditions that must be met in order to act within the political scene of a country:

4. A political party to be formed must have a certain number of its members. This number is different, depending on the law on elections that different states apply.

5. A political party must have its charter program or policy, in which should be expressed its programming guidelines, their internal organizational structure defined and regulated together with the other issues of importance to its operation, and

6. For the purpose of active participation in political life, political parties must be registered within the competent state body. By the act of registering the political partie become legitimate participants within the political life of a country. ${ }^{2}$

${ }^{1}$ Arsim Bajrami, Parliamentary Democracy, Prishtina 2005, p. 164
2 Ibid, p.. 165 


\section{PARTY SYSTEMS}

The party system is a set of related parties between them with a logical relationship. To assess a party system should be considered their horizontal interaction, competitiveness, between at least two parties and it must be considered their vertical interdependence between many elements such as: voters, competing political parties, parliament and government. This means that competition between parties develops, it is defined and has consequences on different plans on: the electoral and parliamentary government. Since these different plans interact, they influence in determining the nature and quality of different party systems. ${ }^{1}$

The initial impulse for the analysis and classification of party systems has been given by Duverger. In his classical study (1951) Duverger already gets limited to the difference of party systems on the basis of a single criterion and simple: the numerical one. So, party systems classified by him are: a single party, bipartisan and multi-party.

- Systems of autocratic regimes are characterized "with a single party". These systems cannot exist in democratic regimes. - Bipartisan systems that are characterized in the democracies like the British and the United States, considered more efficient because of the stability of the government. Such a system is possible only when the parliament is always dominated by two large parties, able to form a monochrome government.

- Multi-party systems are characterized in the most of democracies, born in heterogeneous and unstable coalitions.

According to Duverger theory, bipartisan systems are influenced by the majority electoral system with a single round of elections, whereas the multi-party one functions as a proportional system. Obviously the numerical criterion has its own value, but, as Sartori proposes, it should be integrated with one another, which means the criterion of relevance. Basically the numerical criterion is used to define roughly the format of party systems; The criterion of importance over the parties serves to explain the mechanisms of party systems. ${ }^{2}$ According to Sartori, there are two main criteria of importance. The first is the ability of the parties to come to the formation of the coalition government. Some parties may be considered small due to the percentage of the electorate who voted for them and the number of seats they have ensured in parliament, but in some cases this might be considered a very useful result, when in some cases it sufficiently necessary for the formation of the ruling coalition. Such was the outcome of the Socialist Movement for Integration in Albania, which in 2009 elections managed to get only $4.85 \%$ of the nationwide votes or four seats in the total. In these conditions when the Democratic Party coalition provides 70 seats (minimum to secure a parliamentary majority is 71 seats) and the Socialist Party had 66 seats, it was understood that the value that four LSI seat had the crucial importance into forming the ruling majority. Inasmuch as these parties in this case possess the potential of coalition party, they absolutely deserve to be the "assessed ones". By applying these two criteria it becomes possible a suitable evaluation of the parties and thus they determine the format of the party system.

The third criterion by Sartori is the ideological difference between the parties or polarization in the time when the negotiations for the coalition are being held. In some multi-party systems exist some parties that stand ideologically very distant from one another they cannot create alliances with other parties in such situations. ${ }^{3}$ n the Western democracies such parties to be compared have been the fascist parties and communist parties. Today there are parties of the extreme right and racist.

\section{THE TRANSFORMATION OF PARTY SYSTEM}

Party systems, including those from the politicized pluralism, result transformed into a more or less traumatic ways, as in the case of the passage from the Fourth French Republic into the Fifth, or as in Italian transition still without finishing of a new set of party system. According to Duverger, party systems can vary in four different ways: rotation, lasting division, preponderance, and leftism. Alteration is mainly characterized by pendulous periodic movement and represents a few problems, except its location, i. e. the most likely to effectively bipartisan systems or with a concrete dynamic bipolarity. In

\footnotetext{
1 Ylli Bufi, The Temple of Democracy, Tirana, 2010, p.129.

2 Ibid. p.130.

3 lbid.
} 
the early 90 s of the twentieth century everywhere the new democracies of Europe, in the southern, eastern and central Europe as well, bipolar competition of the parties seems to have become more widespread and practiced with the success of bringing significant and frequent alternatives.

Stable division is defined as the absence of significant changes between the parties over a long period of time, which is measured with reference of two elements: "small differences between the two electoral deviations in terms of rare movements in the longer term periods". Probably Italian electoral history at least from 1953 until 1976, has experimented exactly this type of change or as "no change" with the election continuity of different parties by widely sustaining unchanged or very stable. ${ }^{1}$

Preponderance is characterized by the existence of a party that is "going forward in those political positions, that for a period of time it creates a clear distance from its rivals" and if accidentally loses the elections, then, it keeps its dominant position, which allows quick turn to the government for another long period of governance.

Finally, the leftism undergoes through a slow but regular slide towards the left that appears in various forms: f) The forming of new central leftist parties from the old parties, that provoke their slaw slide towards the right and brings about the disappearance or merging of them.

g) Breakdown of all parties on the right to the benefit of the parties of the left, without the disappearance or creation of new ones,

h) Keeping the global balance between the two blocs with their strengthening within the left parties (the Communists at the expense of the Socialists, the Liberals at the expense of the Conservatives);

i) replacement of the old party of the Left with a new party more dynamic and without making concessions; j) The establishment of the Left party mainly at the expense of all others.

\section{THE TYPOLOGY OF POLITICAL PARTIES}

The party systems the same as the political parties can be distinguished on the basis of certain criteria. In this regard, the parties can be classified in accordance with a number of different criteria, which is specified on the basis of: their level of organization, their social objectives, the social classes that they want to approach and from their position or political system they represent. Some political parties can be classified and based on their names, which often reflect the specific sociopolitical goals that the parties want to be identified with.

According to their level of organization, the differences among parties are: the party of the electorate and parties with their membership. Parties based on their electorate are less attached to a larger membership, but they are particularly active in the field of elections. The relationship to their voters for such a party is usually weak. Parties related to their membership require larger membership, possibly in all parts of the country and in different categories. Traditionally, parties are popularly based, and they are as working parties that try to have a sort of well organized apparatchik within the party together with a large membership.

Regarding the socio-political criteria of the aspiration of the political parties, we can distinguish between those parties seeking social or political changes within the existing democratic order and the parties which appear to make changes by radical means, extremist or revolutionary ones.

The first group consists of conservative parties, liberal, Christian democratic, and partly socialist, and also by parties that define or identify themselves through religion or belief as long as it does not represent the extremist positions. The second group mainly belong to extreme leftist or rightist parties and among them are communist parties, besides the others. ${ }^{2}$

Conservative parties: such parties wish to maintain the "approved order" or restore it. They are skeptical about change

\footnotetext{
1 Ylli Bufi, The Temple of Democracy, Tirana, 2010, p. 137.

2 www.kas. doc/kas de/wf/
} 
and innovation i. e. about perceptions and the role of the family, and alternative models of life (i. e. the same-sex marriages). They also do not want the transfer of national sovereignty to supranational institutions, but they are aware that ideas, values and traditional principles cannot be held continuously without those needed moderate reforms.

Liberal parties: such parties support the rights of individual freedom and emphasize the democratic character of the constitution. Traditionally, they are anti-clerical and mostly committed to a free market economy.

Social democratic parties: such parties most closely are related to labour movements and their political concepts based on social equality of the people; they give to the state to have a strong regulatory role in the economy and society.

Socialist parties: such parties also appear in a close connection with the workers' party and movements, but they represent a more radical approach to achieving social equality; the abolition of private ownership of the means of production and a state-led economy are among the main targets of these parties. ${ }^{1}$

Parties oriented on religion are considered as distinct forms of parties that are characterized by their socio-political objectives. Worldwide, a large number of parties are based on some more, and some less religious convictions, these are Christian or Demo-Christian party, Islamic, Hindu which establish their programs based on the values and standards of religion or belief. It can lead to significant differences within such political programs depending on how individual parties consider their religious position in respect of the individual rights or political democracy. European Christian Democratic parties are committed to individual freedoms, social solidarity and justice, self-responsibility of citizens and a discrete role of the state under the supervision of economic and social actors. ${ }^{2}$

\section{DEMOCRATIC TRADITION IN KOSOVO}

Democracy, as a pluralism of political alternatives, is a new experience for Kosovo. Although multi-party system is installed at the same time when political pluralism was spread throughout South East Europe, the new system was being developed under the conditions of repression since the abolition of Kosovo's autonomy from Serbia, in 1989, and it did not allow any room for a genuine pluralistic and democratic political life. Although during the 1990s in Kosovo there began acting more than a single political party, so under these conditions of repression a couple of parties were formed, beginning with the Democratic League of Kosovo, the Social-democratic Party of Kosovo, the Kosovo Parliamentary Party, Christian Democratic Party and Liberal Party are some of the parties that existed during the period before the war - however they did operate in an environment that did not allow being developed such a normal political life and democracy.

After the war ended, there was created a new ambient for political action and party. Many of the old parties continued to operate and were established other parties such as the Kosovo Democratic Party, the Alliance for the Future of Kosovo, New Kosovo Alliance, the Coalition VAKAT, the Independent Liberal Party, the Turkish Democratic Party of Kosovo, Vetvendosje Movement etc. In the new space created, these parties began to make political competition and seek a vote of the citizens, marking a major step forward in the installation of democratic practice in Kosovo. Only after the war in Kosovo, it could be stated that it started to felt a genuine political transition period from one-party system to a pluralist system. It was a delayed transition or a status quo more than a decade.

More than another decade after the war, much more remains to be done in consolidating democratic practices in political life in Kosovo, including political parties and their inner democratisation. The main drawback of this process was the emergency phase of economic and social reconstruction which was found Kosovo society after the end of the war. Coping with the immediate need for physical reconstruction of settlements, in order to meet immediate needs for physical survival - in the first years after the war, as well as the consolidation of local institutions, without having satisfying time to focus on economic development and social policy years right after the emergency phase, therefore, the political parties have not been able to develop and compete with crucial policy issues. ${ }^{3}$ Specifically, until Kosovo has not consolidated its economy, then certainly parties will not be able to articulate different policies for example adequate tax policy, but they will be limited on their sources that would bring sustainable economic development. In short, the place was not so far to the point where the political parties have an imperative of being profiled by the ideologies they have been promoting so far. On February 17, 2008, the Provisional Institutions of Self-Government declared Kosovo an independent state. With this new situation there were opened the doors for the transfer of all state powers to local institutions. Post-independence phase

\footnotetext{
${ }^{1}$ lbid.

2 lbid.

${ }^{3}$ KIPRED, Strengthening the statehood of Kosovo through the democratization of political parties, Prishtina 2012, p.9. 
was characterized by the establishment of other state institutions that previously had not existed or had been administered by international missions. This has been an institutional and democratic step towards the consolidation process which now appears as a major challenge for our society. It can be expected that with the economic and social development will begin to articulate the programmatic orientation and political parties and this would also consolidate the political scene in Kosovo whatsoever.

\section{Summary}

The analysis over the role of political parties in relation to constitutional government in the country shows that Kosovo society is facing the challenge of determining the power of political parties. The parties are a vital part of democracy and political competition, but contrary to the country's aspirations for effective and sustainable democracy, they are being imposed even as dominant factors of the constitutional state system. The political parties have been consequently promoting the values of democracy and the creation of a political system totally opposite to dictatorial system - the model of 'party -state', but in recent years in many cases they are showing the mentality of the old system, including the tendency of maintaining political monopoly over the state and society. The strength of the parties in a democratic system is a global phenomenon, but unlike the Western model, where against this politicizing trend are operating state constitutional mechanisms that give immunity to the institutions in Kosovo, but unfortunately these mechanisms are still underdeveloped or with dysfunctional results. Challenges and needs of the Euro-Atlantic integrations should also be focused on reducing power of political parties being imposed, on the one hand, and increasingly empowering the constitutional bodies, on the other. As strong and effective democratic institutions and the rule of law will be, as lower will be the negative impact of political parties on state and society. In facing these challenges, political parties have a special responsibility as well. The process of democratization of the political parties will have the benefit of lowering the number of political parties.

\section{Bibliography}

1. Bajrami, Arsim : The Theory and parliamentary practice, Prishtina 1997

2. Bajrami, Arsim : The Kosovo right to transition, Prishtina 2002

3. Martins, Temistocle : Dirito Constituzionale, Tirana 2011

4. Saliu, Kurtesh : The Constitutional Right, Prishtina 1998

5. Bajrami, Arsim : Parliamentary Democracy, Prishtina 2005

6. Omari, Luan : Parliamentary System, Tirana 2000

7. Bufi,Ylli : The Temple of democracy,Tirana 2010

8. Hofmeister, Wilhelm dhe Grabow, Karsten: Political Parties, Scopje 2013

9. KIPRED: Strengthening the statehood of Kosovo through the democratization of political parties, Prishtina, 2012

10. www. kas. de/wf/doc/kas_33531-1522-2-30.pd 